\title{
Diagnostic Efficacy of Radiology in the Diagnosis of Giant Cell Tumour of Bone
}

\author{
Afia Akhter1, Mohammad Serajus Saleheen², Nadira Majid³, \\ Syed Salahuddin, Kwazi Dil Afroz ${ }^{5}$, Md. Rezwanur Rahman6, Syed Mukarram Ali7
}

\begin{abstract}
Background: Giant cell tumour (GCT) is an aggressive and potentially malignant lesion. Microscopic feature reveals osteoclast like giant cells in a mononuclear stromal cells background. The mononuclear stromal cell is interpreted as neoplastic. Objective: As radiological diagnosis is non invasive and cost effective in comparison to histopathological diagnosis, considering the patients' compliance, the aim of the study was to observe the diagnostic efficacy of radiology in diagnosis of GCT. Materials and method: This cross sectional study was carried out in the department of Pathology, Delta Hopital Ltd., Dhaka, Bangladesh from July 2011 to December 2012. A total of 30 study subjects were enrolled in the study irrespective of age and sex. Biopsy material and relevant data of clinically suspected cases of GCT along with radiology report were sent from National Institute of Traumatology and Orthopaedic Rehabilitation (NITOR), Dhaka, Bangladesh. Histopathological diagnosis was made by expert pathologists. Results: Mean ( $\pm S D)$ age of the study subjects was 29.20 ( \pm 7.34$)$ years with highest number of patients were observed in $3 \mathrm{rd}$ decade and female was predominant (60\%) with a male female ratio of 1:1.5. Common site of GCT was around knee (50\%). Among 30 clinically diagnosed GCT, 25 (83.3\%) cases were radiologically diagnosed as GCT, 2 (6.7\%) diagnosed as fibrous dysplasia, 1 (3.3\%) as chondroblastoma, 1 (3.3\%) as simple bone cyst and 1 (3.3\%) as aneurysmal bone cyst. However among 30 clinically diagnosed GCT, $28(93.3 \%)$ patients were histopathologically diagnosed as Giant cell lesion and rest 2 (6.7\%) patients diagnosed as fibrous dysplasia. The sensitivity, specificity, positive predictive value, negative predictive value and accuracy of radiological diagnosis of GCT were found to be 92.6\%, 100.0\%, 100.0\%, 40.0\% and 90.0\%, respectively. Conclusion: Radiology can be effectively used as a screening tool in diagnosing GCT.
\end{abstract}

Keywords: Giant cell tumour; radiology.

Delta Med Col J. Jan 2014;2(1):13-16

1. Assistant Professor, Department of Pathology, Delta Medical College, Dhaka, Bangladesh.

2. Clinical Assistant, Department of Orthopaedics, National Institute of Traumatology and Orthopaedic Rehabilitation, Dhaka, Bangladesh.

3. Associate Professor, Department of Pathology, Delta Medical College, Dhaka, Bangladesh.

4. Senior Consultant (Histopathology), Delta Hospital Ltd., Dhaka, Bangladesh.

5. Consultant (Histopathology), Delta Hospital Ltd., Dhaka, Bangladesh.

6. Associate Professor, Department of Biochemistry, Delta Medical College, Dhaka, Bangladesh.

7. Professor of Pathology.

Correspondence: Dr. Afia Akhter. e-mail: saleheen_mmc@yahoo.com

\section{Introduction}

Giant cell tumour (GCT) is still one of the most obscure and intensively examined tumours of bone. Its histogenesis is uncertain. The World Health Organization has classified GCT as "an aggressive, potentially malignant lesion" which means that its evolution based on its histological features is unpredictable. 1 Statistically, $80 \%$ of GCTs have a benign course, with a local rate of recurrence of $20 \%$ to $50 \%$. About $10 \%$ undergoes malignant transformation at recurrence and $1 \%$ to $4 \%$ gives pulmonary 
metastases even in cases of benign histology. ${ }^{2}$ Giant cell tumour of bone is a lesion of uncertain origin, which represents 4 to $9.5 \%$ of all primary bone tumours and about $10 \%$ of malignant primary bone tumours. 3

Giant cell tumour is also referred to as osteoclastoma, because it is composed of many multinucleated osteoclast like giant cells. ${ }^{4}$ Typically it occurs in skeletally mature patients aged betwen 20 to 50 years. A slight female predominance is noted with the male: female ratio of $1: 1.3$. The tumour is hardly seen before closure of epiphysis, and characteristically it extends up to the subarticular bone plate. 5 The most frequent site of GCT is around the knee joint including the distal femur and proximal tibia. ${ }^{3}$

Diagnosis of GCT of bones depends mainly on clinical and radiological examination, but biopsy is essential to confirm the diagnosis. ${ }^{3}$ Pain, swelling, restricted joint motion and pathological fractures are the common clinical findings. Radiologically, lytic (radiolucent) lesion is usually eccentric, epiphyseal, and expansile with a peripheral rim of reactive bone. In aggressive lesions, the cortex is ballooned; subchondral bone plate is ill defined with formation of 'soap-bubble' appearance. Radiologically, cyst like lytic lesion (radiolucent area) is also seen in simple bone cyst, aneurysmal bone cyst, fibrous cortical defect, fibrous dysplasia, chondroma, chondromyxoid fibroma, chondroblastoma and brown tumour of hyperparathyroidism. 6 Macroscopically, the tumour looks reddish, fleshy that comes away easily in pieces, but incompletely when curetted. Histopathology reveals osteoclast like giant cells in mononuclear spindle cells (stromal cells) background. ${ }^{3}$ These mononuclear stromal cell is interpreted as neoplastic. 6 On microscopic examination the aspirates are very cellular that contain two main cell types in variable proportions: large, multinucleated, benign appearing osteoclasts and polygonal or short spindle cells with a single nucleus. ${ }^{7}$

Though histopathological diagnosis is confirmatory test, but it depends on experience and expertise, which is not always available in all centers of our country. Radiological diagnosis is non invasive and cost effective in comparison to histopathological diagnosis. Keeping in mind the above conditions and considering the patients' compliance, our aim was to observe the diagnostic efficacy of radiology in the diagnosis of GCT.

\section{Materials and method}

This cross sectional study was carried out in the department of Pathology, Delta Hospital Ltd., Dhaka, Bangladesh, from July 2011 to December 2012, to observe the diagnostic efficacy of radiology in the diagnosis of GCT. A total of 30 clinically suspected case of GCT were enrolled in the study irrespective of age and sex. Data were collected when biopsy samples were sent from National Institute of Traumatology and Orthopaedic Rehabilitation (NITOR), Dhaka, Bangladesh along with patients clinically suspected diagnosis of GCT and radiology report. Histopathological diagnosis was made by pathologists from the biopsy sample using haematoxylin and eosin stain. The diagnostic efficacy of radiology were evaluated in terms of sensitivity [Sensitivity= $\mathrm{a} /(\mathrm{a}+\mathrm{c}) \mathrm{x} 100$. Here, $\mathrm{a}=$ true $(+) \mathrm{ve}, \mathrm{c}=$ false (-)ve], specificity $[$ Specificity $=d /(b+d) \times 100$. Here, $b=$ false $(+) \mathrm{ve}, \mathrm{d}=$ true $(-) \mathrm{ve}]$, positive predictive value (PPV) $[\mathrm{PPV}=\mathrm{a} /(\mathrm{a}+\mathrm{b}) \times 100]$, negative predictive value(NPV) $[\mathrm{NPV}=\mathrm{d} /(\mathrm{c}+\mathrm{d}) \times 100]$ and diagnostic accuracy [diagnostic accuracy $=(a+d) /(a+b+c+d) \times 100]$.

\section{Results}

A total number of 30 clinically suspected cases of Giant cell tumour were included in the study. In this study, the highest number of patients $18(60.0 \%)$ were observed in 3rd decade and lowest number 3 (10.0\%) patients was observed in 5 th decade (Table I). The mean $\pm \mathrm{SD}$ of age was $29.20 \pm 7.34$ years with range of 20-50 years.

Table I: Age distribution of the study subjects $(\mathbf{N}=\mathbf{3 0})$

\begin{tabular}{lcc}
\hline Age (in year) & Frequency & Percentage \\
\hline $20-30$ & 18 & 60.0 \\
$31-40$ & 9 & 30.0 \\
$>40$ & 3 & 10.0 \\
\hline
\end{tabular}

Table II shows the sex distribution. Among the study subjects male was found $12(40.0 \%)$ and female was 18 $(60.0 \%)$. The male to female ratio was $1: 1.5$.

Table II: Sex distribution of the study subjects $(\mathrm{N}=30)$

\begin{tabular}{lcc}
\hline Sex & Frequency & Percentage \\
\hline Male & 12 & 40.0 \\
Female & 18 & 60.0 \\
\hline
\end{tabular}

Table III shows proportions of site of involvement awhere about $50 \%$ of GCT occurs around knee, followed by distal radius (20\%) with least in calcaneum. 
Table III: Distribution of the study subjects according to site of involvement $(\mathrm{N}=30)$

\begin{tabular}{lcc}
\hline Site & Frequency & Percentage \\
\hline Distal femur & 9 & 30.0 \\
Proximal tibia & 6 & 20.0 \\
Distal radius & 6 & 20.0 \\
Distal ulna & 3 & 10.0 \\
Proximal femur & 3 & 10.0 \\
Proximal humerus & 2 & 7.0 \\
Calcaneum & 1 & 3.0 \\
\hline
\end{tabular}

Among 30 clinically diagnosed GCT, 25 (83.3\%) patients are radiologically diagnosed as GCT, 2 (6.7\%) diagnosed as fibrous dysplasia, 1 (3.3\%) as chondroblastoma, $1(3.3 \%)$ as simple bone cyst and 1 $(3.3 \%)$ as aneurysmal bone cyst (Table IV).

Table IV: Radiological diagnosis of study subjects $(\mathrm{N}=\mathbf{3 0})$

\begin{tabular}{lcc}
\hline Radiological diagnosis & Frequency & Percentage \\
\hline Giant cell tumour & 25 & 83.3 \\
Fibrous dysplasia & 2 & 6.7 \\
Chondroblastoma & 1 & 3.3 \\
Simple bone cyst & 1 & 3.3 \\
Aneurysmal bone cyst & 1 & 3.3 \\
\hline
\end{tabular}

Histopathologically 28 (93.3\%) patients are diagnosed as giant cell tumour and rest $2(6.7 \%)$ patients are diagnosed as fibrous dysplasia (Table V).

Table V: Histopathological diagnosis of the study patients $(\mathbf{N}=\mathbf{3 0})$

\begin{tabular}{lcc}
\hline Histopathological diagnosis & Frequency & Percentage \\
\hline Giant cell lesion & 28 & 93.3 \\
Fibrous dysplasia & 2 & 6.7 \\
\hline
\end{tabular}

Table VI shows the distribution of histopathological and radiological diagnosis, from which diagnostic statistical test in terms of sensitivity, specificity, PPV, NPV and accuracy for radiological diagnosis of GCT are calculated.
Table VI: Distribution of histopathological and radiological diagnosis $(\mathrm{N}=\mathbf{3 0})$

\begin{tabular}{lccc}
\hline $\begin{array}{l}\text { Radiological } \\
\text { diagnosis }\end{array}$ & $\begin{array}{l}\text { Histopathological } \\
\text { diagnosis }\end{array}$ & Total \\
\hline Yes & No & \\
Yes & 25 & 0 & 25 \\
No & 3 & 2 & 5 \\
Total & 28 & 2 & 30 \\
\hline
\end{tabular}

Table VII: Diagnostic efficacy for radiological diagnosis of GCT

\begin{tabular}{lc}
\hline Diagnostic tests & Frequency \\
\hline Sensitivity & $89.3 \%$ \\
Specificity & $100.0 \%$ \\
PPV & $100.0 \%$ \\
NPV & $40.0 \%$ \\
Accuracy & $90.0 \%$ \\
\hline
\end{tabular}

Photomicrograps of microscopy and radiological findings of GCT are shown in Fig 1 and 2.

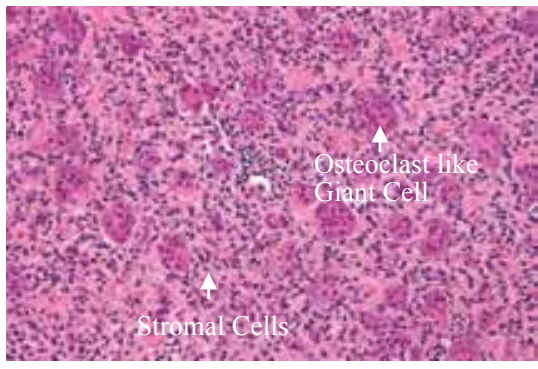

Fig 1: Microscopic picture of giant cell tumour of bone

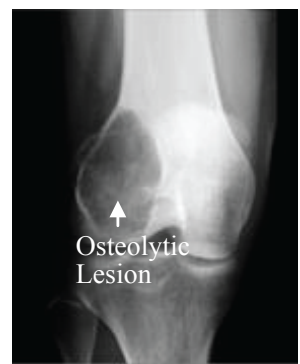

Fig 2: Radiological picture of giant cell tumour of lower end of femur

\section{Discussion}

Giant cell tumour usually appears in mature bone, comprising 4 to $9.5 \%$ of all primary bone neoplasm. In this current study, the highest number of patients, 18 $(60.0 \%)$ were observed in $3 \mathrm{rd}$ decade and lowest number $3(10.0 \%)$ were observed in 5 th decade with mean age of 31 years, which closely resemble a study on 52 patients done by Khalil et al. ${ }^{3}$ McDonald et al. ${ }^{8}$ found same the mean age. In the present study male was found $12(40.0 \%)$ and female was $18(60.0 \%)$, that is female is predominant and male female ratio was 1:1.5. Lim and $\operatorname{Tan}^{9}$ reported that male female ratio was 1:1.2, which correlates with this study. 
In this study, 30\% GCT of bone occur in distal femur, $20 \%$ occur in proximal tibia, $20 \%$ in the distal radius, $10 \%$ distal ulna, $10 \%$ proximal femur, $7 \%$ proximal humerus and $3 \%$ in the calcaneum. Willis 10 observed in his study that commonest site in order of frequency was distal femur, proximal tibia, distal radius, proximal humerus, distal ulna, proximal fibula respectively, which is closely resembled with the current study.

In the present study, among 30 cases of clinically suspected GCT, $25(83.3 \%)$ cases were diagnosed radiologically as GCT and remaining $5(16.7 \%)$ cases as other than GCT, but histopathologically 28 (93.3\%) cases were confirmed as GCT. The sites of the 5 cases which were not radiologically diagnosed as GCT were proximal femur and humerus, which correlates with the study done by Jacobs. ${ }^{11}$

Though we got remarkable diagnostic efficacy for radiological diagnosis for GCT tumor, specifically regarding specificity and positive predictive value (100\% for each); still it must not be generalized as our sample size is not representative. Moreover as GCT is an aggressive, potentially malignant lesion, no single case of clinically suspected GCT should be declared negative only on the basis of radiology. Again no tumour should be accepted as an osteoclastoma without histological confirmation. So, if any confusion arise in diagnosis of GCT, it is better to evaluate the cases using the radiological, histopathological and biochemical modalities. Though biochemical evaluation was not considered in this study, but as a non invasive and cost effective tool radiology is of great help in screening purpose.

\section{Acknowledgement}

The authors acknowledege Prof. (c.c) Dr. Shaikh Shofiur Rahman for his expert opinion regarding radiological findings.

\section{References}

1. Bassiony AA, Abdelrahman M, Abdelhady A, Assal MK. Resection Arthrodesis for the Management of Aggressive Giant Cell Tumor of the Distal Femur. Indian J Orthop. 2009;43(1):67-71.

2. Szendröi M. Giant-cell Tumour of Bone. J Bone Joint Surg [Br]. 2004;86:5-12.

3. Khalil ESA, Younis A, Aziz SA, Shahawy ME. Surgical Management for Giant Cell Tumour of Bones. Journal of the Egyptian National Cancer Institute. 2004;16(3):144-52.

4. Oh JH, Yoor PW, Lee HS, Cho HS, Kim WS, Kim HS. Surgical Treatment of Giant Cell Tumour of Long Bone With Anhydrous Alcohol Adjuvant. International Orthopaedics. 2006;30(6):490-94.

5. Bajracharya S, Khanal GP, Nepal P, Sherstha BP, Singh M. Giant Cell Tumour of Distal End Femur: A Challenge in Treatment. Acta Orthop Bras. 2009;17(2):58-61.

6. Aston W, Briggs T, Solomon L. Tumors. In: Solomon L, Warwick D, Nayagam S, editors. Apley's System of Orthopaedics and Fractures. 9th ed. London: Hodder Arnold Hodder education; 2010. p.202-4.

7. Unni KK, Inwards CY, Bridge JA, Kindblom LG, Wold LE. Giant Cell Tumor. In: Silverberg SG, editor. Tumors of the Bones and Joints. AFIP Atlas of Tumor Pathology. Series 4. Vol 2. Washington DC: American Registry of Pathology; 2005. p, 281-98.

8. McDonald DJ, Sim FH, Mcleod AR, Dahlin DC. Giant Cell Tumor of Bone. J Bon Joint Surg. 1986;68(2): 235-42.

9. Lim YW, Tan MH. Treatment of Benign GCTs of Bone in Singapore. Ann Acad Med Singapore. 2005;34(3):235-37.

10. Willis RA. The Pathology of Osteoclastoma or Giant Cell Tumor of Bone. J Bon Joint Surg. 1949;31(2): 236-40.

11. Jacobs P. The Diagnosis of Osteoclastoma (Giant Cell Tumour): A Radiological and Pathological Correlation. British Journal of Radiology. 1972;45:121-36. 